\title{
THE DESIGN OF MOBILE APPLICATION FOR TEACHER AND PARENTS COMMUNICATION IN INDONESIAN SCHOOL
}

\author{
Sholeh Hadi Setyawan ${ }^{1}$, Dhiani Tresna Absari², Susana Limanto ${ }^{3 *}$, Andre \\ ${ }^{1}$ Information System Department, University of Surabaya, Surabaya, Indonesia \\ ${ }^{2}$ Information System Department, University of Surabaya, Surabaya, Indonesia \\ ${ }^{3}$ Informatics Engineering Department, University of Surabaya, Surabaya, Indonesia \\ ${ }^{4}$ Informatics Engineering Department, University of Surabaya, Surabaya, Indonesia \\ E-mail: susana@staff.ubaya.ac.id
}

\begin{abstract}
One of the success factor to achieve education goals is the good communication between the student's parents and the school. Most of Indonesian schools use written communication in form of communicator book, renewed yearly when the student move to the new grade. All of the important information contained in the conversation will be lost if the book is missing, torn, damaged or replaced by the new book. The response time of the conversation is very slow, parent should wait the answer from the school until the student goes home. A mobile application is designed to replace the communicator book electronically. The application is hybrid, enables the parent to communicate easily to the class teacher, counselors, health services and also the school managements. The design has been reviewed dan feedback given from the users.
\end{abstract}

Keyword: Electronic communication, School communicator

\section{INTRODUCTION}

The good communication between parents and teachers plays important role to support the achievements of educational goals. Teachers need to daily inform the parents about the student's activities, achievements, homeworks, events and other official informations from the school. On the other hand, the parents also need to communicate to the school, either to the class teacher, the school counselor, the school administration or the principals about many aspects of the students. The regular bi-directional communication is required both to enhance academic achievements and students mental well-being (Thornton, 2011).

The media of the communication is usually a communicator book. The students should bring the book everyday. The teachers and the parents communicate by writing messages and informations on the book. The content of the book may vary for every school, but the main fields of information are the date of the message, subject, the message body, and the sign of both teacher and parent to verify that both party has already read the message or information.

Because of the nature of the book, some problems may arise. The book can be missing, left at home, torn or damaged. In that condition, the informations stored on the book will also be lost without any possibility to restore. Teachers or parents may have problem with writing by hand. The handwriting message may be difficult to read by other people. The result of this problem may lead to misunderstanding or miscommunication. The example of the written message is shown in Figure-1. The first column is the date of the message, followed by the message content, and the place for teacher and parent's signs.

The communication book is renewed yearly when the students enter the new level. All of the communication records stored on the old book are discarded. The parents usually should rewrite important messages to the new class teacher. On the other side, if the teacher need to send the same message to all of the parents in his class, he should write the same message on each student's book. Depends on the size of the class and the size of the message, this activity may consume the quality time that the teacher can use to do more important things to his class.

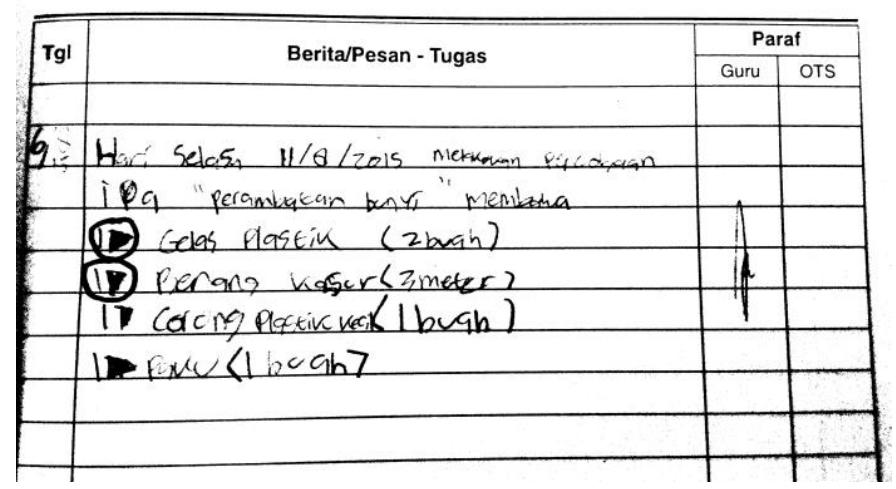

Figure-1. The content example of communication book

\section{Mobile APPLICATIONS IN EdUCATION}

The rapid growth of smart phones and PC tablets usage drives the mobile application development. The mobile applications have the main different characteristics such as the less dependent of space and time, more personalization, and more integrated to other mobile application and services.

Among the many fields of the mobile application development, one of the emerging field is the education. Recent studies and developments of mobile application in education are educational game (Zhang and Loeb, 2013), mobile learning system (Petrova, 2007; Sung, et.al., 2005) and interactive learning table (Wilson, 2011). Studies show that mobile applications give better result than desktop applications in language learning (Jarvis and Achilleos, 2013), help to get better skills in math and writing (Aker, Ksoll and Lybbert, 2011).

Many mobile communication applications are available for free e.g. Whatsapp Messenger, Blackberry Messenger, Google Hangout, etc. and may replace the communication book. But because the applications are not integrated to the school database (teachers, students, classes, and parents records), the messages can not be furthermore processed by the school 
information system. Therefore the communication application can't contribute to the school data to be utilized for decision support system by the school management.

\section{REQUIREMENT ANALYSIS}

A requirement analysis should be performed before designing the system, to assure that the design meets the actual requirements of the system users. The analysis begin with a survey to the parents. A series of questions were asked to identify the problems to be solved, the requirements to be implemented and the expectation of the mobile application. The answers were processed and analyzed to generate the list of parents' requirements. The respondents were the parents of sampled play group, kindergarten, primary school and junior high school in Surabaya, Indonesia.

The other survey also conducted for the class teachers and the school managements, to identify the requirements of the school users. The answers of the questionnaires were processed and analyzed. Together with the parent requirements, a list of user requirements was written and become the main input of application design.

The common requirements of the mobile application are:

- The application runs on Android smart-phones

- The application should notify the user when there is a new message or reply. The notifications are also copied to the user's email.

- The user accounts and credentials are generated by system, using email address as the login name. The password is randomly generated, and sent to the user's email address. User can change the password after successfully $\log$ in to the system

- The user can search the messages by keywords, the date, or the destination

- The message can be marked as "urgent"

- "Calendar" view, so the messages can be grouped and searched by date

Parents need to communicate with the school for several reasons like :

- lack of information details from school letters, reports or announcements.

- To inform the student's condition if required, i.e when the students were in recovery condition after sick, when the student need medical attention from the teacher or schooll health services.

The parents requirements for the communication mobile application are :

- The parent may write messages not just to class teacher, but also to school management, school counselors, or school health services person.

- The parent can attach images taken from the mobile device
- The parent may have more than one students in the school. The conversation should be displayed separated for each student

The requirements identified from the teachers and the school management are:

- Teacher can write message to a single parent, multiple parents or all of the parents in his class in a single process

- $\quad$ There are 3 types of informations sent by the teacher: normal message, announcement, or letter from the school.

- Teacher can attach file to the message i.e. images, office documents, etc.

- The teacher can forward the message from the parent to another teacher or school management.

- The teacher can also access the system using web browser, especially to upload files from his computer.

- The teacher can forward a message from the parent to his colleague or to the school managements if needed

- The teacher can re-post old messages

- The teacher make carbon copy to other parents

\section{THE SYSTEM DESIGN}

After examining the requirements, the mobile application should be accessible from web browser, to facilitate the teachers to upload files from their computers. Therefore the application should be hybrid, developed using hybrid framework such as Phonegap (Shotts, 2014).

There are 13 entities designed for the application, as shown in Figure-2. and listed in Table-1.

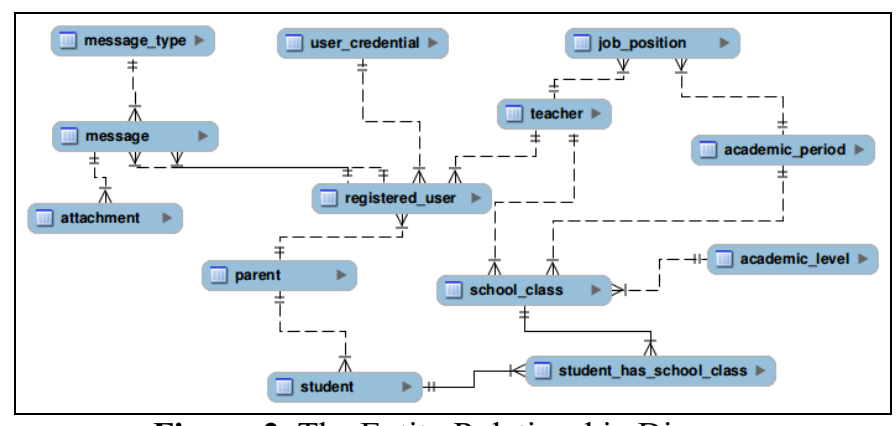

Figure-2. The Entity Relationship Diagram 
Table-1. System entities

\begin{tabular}{|c|c|c|}
\hline No. & Entity Name & Description \\
\hline 1. & message_type & $\begin{array}{l}\text { Define the types of } \\
\text { messages, i.e. } \\
\text { announcement, } \\
\text { conversation, notice, letter } \\
\text { from school, etc. }\end{array}$ \\
\hline 2. & message & $\begin{array}{l}\text { The messages between } \\
\text { parents and schools }\end{array}$ \\
\hline 3. & $\begin{array}{l}\text { message_attach } \\
\text { ment }\end{array}$ & $\begin{array}{l}\text { Define the multimedia } \\
\text { attachement (if required) } \\
\text { for each message }\end{array}$ \\
\hline 4. & registered_user & $\begin{array}{l}\text { The central storage for } \\
\text { usernames and passwords } \\
\text { for each registered user }\end{array}$ \\
\hline 5. & user_credential & $\begin{array}{l}\text { Define the access rights } \\
\text { grouping for the users }\end{array}$ \\
\hline 6. & parent & \\
\hline 7. & student & \\
\hline 8. & teacher & \\
\hline 9. & academic_level & The level/grade of students \\
\hline 10. & academic_period & Yearly set up \\
\hline 11. & job_position & $\begin{array}{l}\text { The job position of } \\
\text { teachers during an } \\
\text { academic_period }\end{array}$ \\
\hline 12. & school_class & $\begin{array}{l}\text { The class opened for each } \\
\text { academic period }\end{array}$ \\
\hline 13. & $\begin{array}{l}\text { Student_has_sch } \\
\text { ool class }\end{array}$ & $\begin{array}{l}\text { The assignment of each } \\
\text { student for each shool class }\end{array}$ \\
\hline
\end{tabular}

The mobile application was designed for several users to handle processes as shown in Figure-3. The users of the applications are the system administrator, the school management, the health services person, the school counselors, the class teachers and the parents.

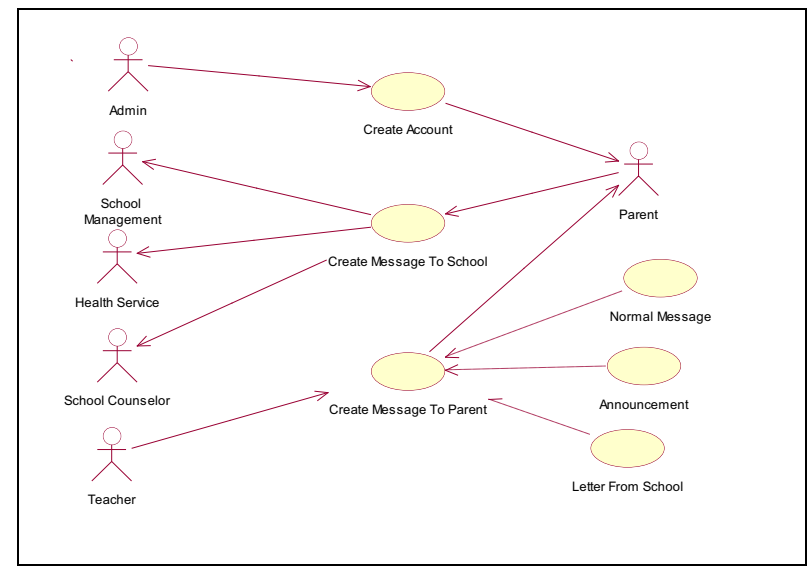

Figure-3. The use case diagram

The mobile application was designed to best suite the major smartphone screens around $4-7$ inches, using Android
Operating System User Interface standards (Lee, 2012). The design of the user interface includes :

1. Login screen: the first screen to show when user first accesses this application, as shown in Figure-4.

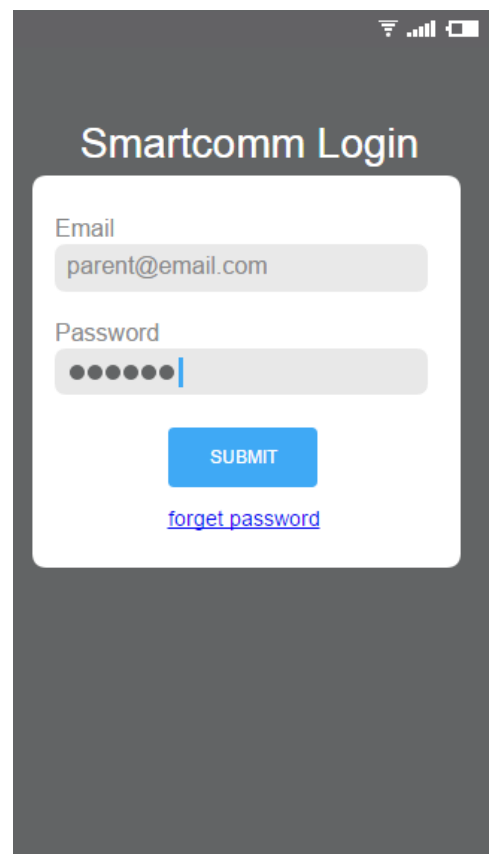

Figure-4. The login screen

2. Inbox : the list of incoming messages, as shown in Figure-5.

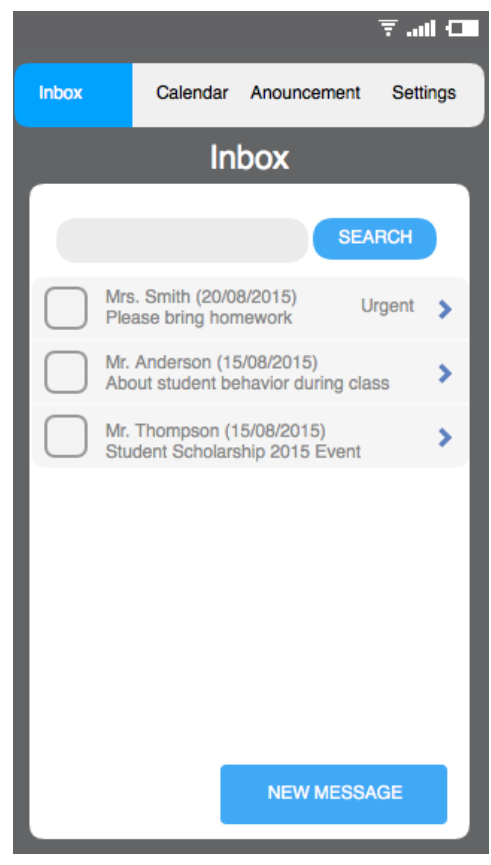

Figure-5. The inbox screen

3. Conversation screen : the time-line conversation messages between parent and the school, as shown in Figure-6. 


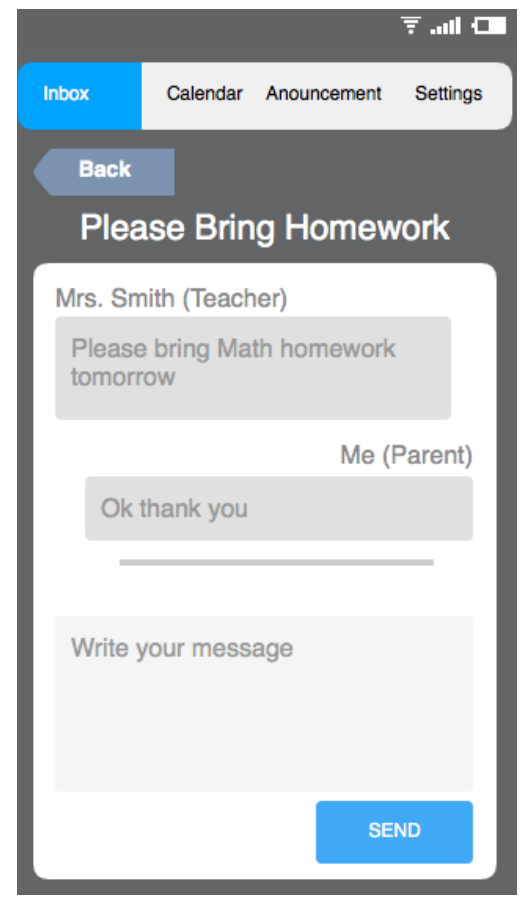

Figure-6. The Conversation Screen

4. Calendar view: to facilitate searching messages based on the date, as shown in Figure-7.

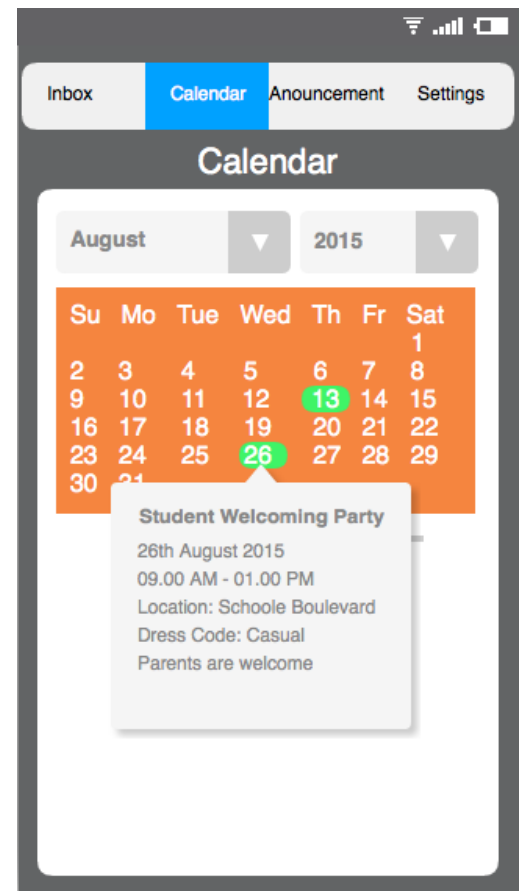

Figure-7. The Calendar View Screen

5. New message creation: user can choose the destination of the message, write the subject and the content, as shown in Figure-8.

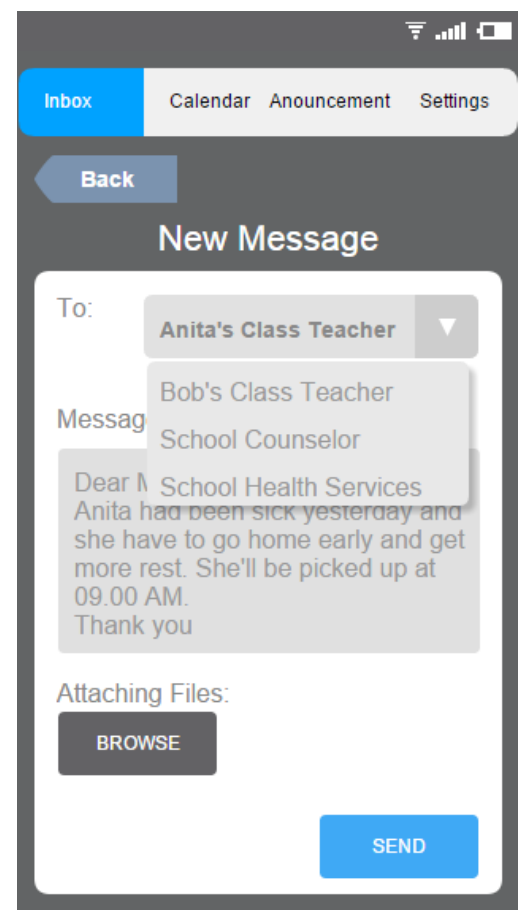

Figure-8. The New Message Screen

\section{CONCLUSION}

The system design validation was done by conducting focus group discussion involving the school managements, the class teachers, the school counselors, the school health services and the parents. The feedback from the respondents about the features and the interfaces has been implemented on this design, and reviewed by the related users.

\section{REFERENCES}

Aker, J.C., Ksoll, C., and Lybbert, T.J., 2011. Can Mobile Phones Improve Learning? Evidence from a Field Experiment in Niger. Medford, Mass., Tufts University; Oxford, UK, University of Oxford; Davis, Calif., University of California, Davis.

http://www.aae.wisc.edu/mwiedc/papers/2011/Aker Jenny.pd f [Accessed September 2015].

Jarvis, H., and Achilleos, M., 2013, From Computer Assisted Language Learning (CALL) to Mobile, The Electronic Journal for English as a Second Language, 16(4), [online], Available at : $<$ http://www.teslej.org/wordpress/issues/volume16/ej64/ej64a2/> [Accessed August 2015]

Lee, W.M., 2012, Beginning Android 4 Application Development. [e-book] Indianapolis:John Wiley \& Sons Inc. Available through : < blogs.wrox.com/files/2013/05/Chapter8-9781118087299-2.pdf $>$

Petrova, K., 2007,. Mobile learning as a mobile business application, International Journal of Innovation and Learning, pp $1--13$

Shelley R.T., 2011. Supporting children's mental well-being in primary school: problem solving through communication and action. PhD. Southern Cross University, NSW. 
Shotts, K., 2014, PhoneGap 3.x Mobile Application Development Hotshot, Brimingham:Packt Publishing.

Sung, M., Gips, J., Eagle, N., Madan, A., Caneel, R., DeVaul, R., Bonsen, J., and Pentland, A., 2005, Mobile-IT Education (MIT. EDU): M-Learning Applications for Classroom Settings, Journal of Computer Assisted Learning 21, pp.229237
Wilson II, G., 2011. Experiences with the Mobile Interactive Learning Table. Master of Science in Computer Science and Application. Virginia Polytechnic Institute and State University.

Zhang, E.Y., and Loeb, L., 2013. Mobile Applications: Games that Transform Education .[pdf], Hanover : Dartmouth Computer Science, Dartmouth College, Available at : $<$ http://www.cs.dartmouth.edu/reports/TR2013-737.pdf [Accessed September 2015] 